УДК 658

DOI: https:/ / doi.org/10.47567/ bomivit.1-3.2020.01

Д. О. Бобровник, аспірант Інституту законодавства Верховної Ради України Адвокатський альянс «Баймуратов і партнери» адвокат bobrovnik.denys@gmail.com ORCID: https:/ / orcid.org/0000-0002-7698-2640

\title{
ОРГАНІЗАЦІЙНО-ЕКОНОМІЧНИЙ МЕХАНІЗМ ВИКОРИСТАННЯ БЕНЧМАРКІНГУ У ПІДВИЩЕННІ КОНКУРЕНТОСПРОМОЖНОСТІ АГРАРНИХ ПІДПРИСМСТВ
} \author{
Postgraduate Student of Legislation Institute of The Verkhovna Rada of Ukraine \\ Barristers alliance «Baymuratov and partners» \\ ORCID: https:/ / orcid.org/0000-0002-7698-2640

\section{ORGANIZATIONAL AND ECONOMIC MECHANISM OF USING BENCHMARKING IN INCREASING THE COMPETITIVENESS OF AGRICULTURAL ENTERPRISES}

D. O. Bobrovnik, barrister bobrovnik.denys@gmail.com

У статті розглянуто організаційно-економічний механізм використання бенчмаркінгу у підвищенні конкурентоздатності аграрних підприємств. Уточнено сутність поняття «бенчмаркінг» для аграрних підприємств. Бенчмаркінг аграрних підприємств розглянуто з динамічного підходу, за якого пропонується розуміти систематичну діяльність аграрного підприємства, головною метою якої $\epsilon$ підвищення конкурентоспроможності підприємства, що досягається шляхом адаптації найкращих методів реалізації бізнес-процесів еталонних підприємств.

Запропоновано авторське визначення поняття «бенчмаркінг аграрних підприємств». сформулювати власний підхід моделі концептуальних засад бенчмаркінгу аграрних підприємств, яка включає функціональне призначення, мету, завдання, предмет, об'єкт та інформаційне забезпечення бенчмаркінгу аграрних підприємств.

Розглянуто організаційно-економічний механізм бенчмаркінгу у підвищенні конкурентоспроможності аграрних підприємств. Встановлено, що особливу роль у бенчмаркінгу відіграють профільні організації, які здійснюють аналіз конкурентів, створюють методики порівняння роботи господарств, формують платформу для взаємодії між агровиробниками, урядовими та неурядовими інститутами, шукають спільні шляхи розвитку сільського господарства. Зазначені організації дотримуються підходу щодо визначення бенчмаркінгу, за якого розуміють процес виявлення, вивчення та адаптації видатних практик та процесів будь-якої організації в будь-якій точці світу, щоб допомогти організації підвищити їі ефективність. 
Бенчмаркінг збирає мовчазні знання - ноу-хау, судження та сприяння. В Україні відкрито напрям бенчмаркінгу українських аграрних компаній, що здійснює аналіз конкурентів або різних підрозділів одного холдингу, який дозволяє спів ставляти їхні показники та визначати кращі галузеві практики.

Ключові слова: бенчмаркінг, аграрний бенчмаркінг, бенчмаркінг аграрних підприємств, конкурентоспроможність, конкурентоспроможність аграрних підприємств.

The article considers the organizational and economic mechanism of using benchmarking to increase the competitiveness of agricultural enterprises. The essence of the concept of "benchmarking" for agricultural enterprises is specified. Benchmarking of agricultural enterprises is considered from a dynamic approach, which offers to understand the systematic activities of agricultural enterprises, the main purpose of which is to increase the competitiveness of the enterprise, which is achieved by adapting the best methods of business processes of reference enterprises.

The author's definition of the concept "benchmarking of agricultural enterprises" is offered. formulate their own approach to the model of conceptual principles of benchmarking of agricultural enterprises, which includes the functional purpose, purpose, objectives, subject, object and information support of benchmarking of agricultural enterprises.

The organizational and economic mechanism of benchmarking in increasing the competitiveness of agricultural enterprises is considered. It is established that a special role in benchmarking is played by specialized organizations that analyze competitors, create methods for comparing the work of farms, form a platform for interaction between agricultural producers, governmental and non-governmental institutions, seek common ways of agricultural development. These organizations follow a benchmarking approach that understands the process of identifying, studying, and adapting the outstanding practices and processes of any organization anywhere in the world to help an organization improve its effectiveness. Benchmarking gathers tacit knowledge - know-how and assistance. In Ukraine, the benchmarking direction of Ukrainian agricultural companies has been opened, which analyzes competitors or different divisions of one holding company, which allows to compare their indicators and identify best industry practices.

Keywords: benchmarking, agricultural benchmarking, benchmarking of agricultural enterprises, competitiveness, competitiveness of agricultural enterprises

Постановка проблеми. За даними Державної служби статистики України аграрні підприємства складають 8\% загальної кількості активних підприємств нашої країни, що дозволяє формувати 10,7\% ВВП. У структурі українського експорту частка аграрної та харчової продукції становить 44,2\% [6]. Зазначені дані свідчать про те, що аграрний сектор відіграє помітну роль структурі вітчизняної економіки, що дозволяє закріпити позиції нашої країни на світовому ринку за допомогою експорту аграрної продукції. 3 метою підвищення конкурентоспроможності аграрних підприємств, що дозволить вітчизняним підприємствам збільшити частку присутності на світовій арені, у тому числі шляхом переймання зарубіжного досвіду, доцільним є використання бенчмаркінгу.

Аналіз останніх досліджень і публікацій. Теоретичні засади бенчмаркінгу досліджено у наукових працях таких вчених, як М. Варгатюк, Даррелл К. Рігбі, 
С. А. Манжос, Т. С. Моршенок, В. Негоденко, О. В. Христенко, М. Щербата. Питання бенчмаркінгу аграрних підприємства висвітлюються у наукових працях Д. Бобровника, О. С. Лаврук, Н. А. Славіної, І. Яців. Зважаючи на значний науковий доробок, і досі існує необхідність у розробці такого організаційно-економічного механізму аграрних підприємств, який дозволить підвищити конкурентоздатність суб'єктів агропромислового комплексу на світовому ринку.

Метою статті $є$ дослідження організаційно-економічного механізму використання бенчмаркінгу у підвищенні конкурентоздатності аграрних підприємств.

Для досягнення поставленої мети необхідно виконати ряд завдань: уточнити сутність поняття «бенчмаркінг» для аграрних підприємств; дослідити концептуальні засади бенчмаркінгу аграрних підприємств; розглянути організаційно-економічний механізм бенчмаркінгу у підвищенні конкурентоспроможності аграрних підприємств.

Виклад основного матеріалу. Розглядаючи питання застосування бенчмаркінгу у роботі аграрних підприємств вітчизняні науковці зазначають, що в сучасних умовах господарювання цей метод управління на професійному рівні мають змогу використовувати лише господарські товариства та частково приватні підприємства, які дійсно зацікавлені у підвищенні до максимально можливого рівня ефективності виробництва, і володіють відповідними фінансовими ресурсами, які можуть бути використані у даному напрямку [10]. Саме тому виникає необхідність у створенні такого організаційно-економічного механізму бенчмаркінгу аграрних підприємств, який уможливить використання цього методу управління на підприємствах аграрного сектору 3 меншими витратами та збільшенням їх конкурентоспроможності.

Ефективним інструментом у прискоренні розвитку аграрних підприємств є бенчмаркінг. Підходи науковців до тлумачення сутності бенчмаркінгу наведено у таблиці 1.

Таблиця 1

Наукові підходи тлумачення поняття «бенчмаркінг»

\begin{tabular}{|c|c|c|}
\hline $\begin{array}{l}\text { № } \\
3 / \Pi\end{array}$ & Автор & Тлумачення \\
\hline 1 & $\begin{array}{c}\text { Даррелл К. Рігбі } \\
\text { [12] }\end{array}$ & $\begin{array}{l}\text { Бенчмаркінг - це метод, який підвищує } \\
\text { продуктивність підприємства за рахунок виявлення та } \\
\text { впровадження кращих практик здійснення економічних } \\
\text { операцій і продажів компаній }\end{array}$ \\
\hline 2 & Морщенок Т. С. [1] & 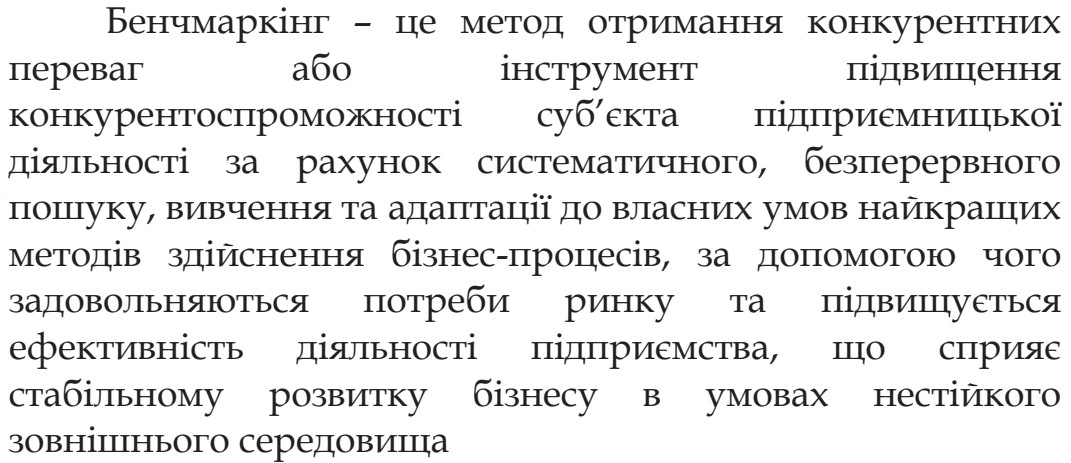 \\
\hline
\end{tabular}




\begin{tabular}{|c|c|c|}
\hline 3 & $\begin{array}{l}\text { Христенко О. В., } \\
\text { Манжос С. А. [9] }\end{array}$ & $\begin{array}{l}\text { Бенчмаркінг - це систематична діяльність } \\
\text { підприємства, яка передбачає вивчення та використання } \\
\text { передового досвіду підприємств визначеної галузі для } \\
\text { поліпшення діяльності даного підприємства та завоювання } \\
\text { ним бажаної конкурентної позиції на ринку }\end{array}$ \\
\hline 4 & $\begin{array}{c}\text { Негоденко В., } \\
\text { Варгатюк М., } \\
\text { Щербата М. [2] }\end{array}$ & $\begin{array}{l}\text { Бенчмаркінг - це метод управління, сутність якого } \\
\text { полягає у виокремленні кращого досвіду } \text { роботи } \\
\text { економічних } \text { агентів, } \\
\text { підприємницької діяльності, та використання його у роботі } \\
\text { інших підприємств, установ, організацій }\end{array}$ \\
\hline
\end{tabular}

\section{Джерело: сформовано автором.}

Як видно з таблиці 1, науковцями бенчмаркінг розглядається як: концепція, процес, особливий вид діяльності, метод отримання конкурентних переваг тощо. Вартим уваги $є$ підхід, запропонований науковцями [2], за якого бенчмаркінг розглядається із використанням статичного та динамічного підходів (рис. 1).

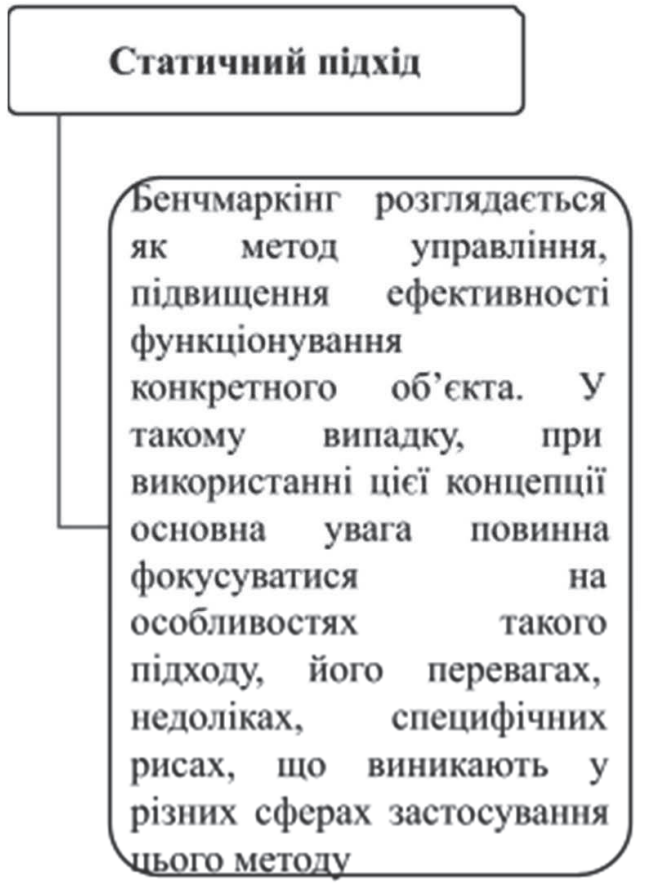

\section{Динамічний підхід}

Бенчмаркінг необхідно вже розглядати як окремий процес, який відбувається у певному часовому відрізку, складається 3 низки окремих процесів, реалізація яких залежить також від системи різних чинників, зокрема специфічних рис того об'єкта, якість управління якого плануеться підвищувати. Таким чином динамічний підхід дозволяє розглядати бенчмаркінг як складну систему, яка постійно розвивається, змінюється та залежить у своєму функціонуванні від впливу низки конкретних специфічних рис інших явиш

\section{Рис. 1. Статичний та динамічний підходи до визначення сутності}

\section{«бенчмаркінгу»}

Джерело: сорормовано автором на основі [2].

Як зазначають I. Яців, Д. Бобровник, бенчмаркінг розвиває аналіз конкурентоспроможності аграрних підприємств, що обмежується вивченням конкурентів - їх продукції, методів ведення бізнесу, витрат і технологій, економічних і фінансових показників, відносин із споживачами та конкурентами. Бенчмаркінг допоможе зрозуміти, яким чином працюють найкращі підприємства, та досягти їх рівня, отримати значно кращих результатів за рахунок зменшення витрат, 
підвищення продуктивності праці, оптимізації стратегічних напрямів діяльності підприємства, що особливо важливо для всієї галузі агропромислового комплексу та України в цілому [10]. На нашу думку, бенчмаркінг аграрних підприємств доцільно розглядати 3 динамічного підходу, за якого пропонується розуміти систематичну діяльність аграрного підприємства, головною метою якої $є$ підвищення конкурентоспроможності підприємства, що досягається шляхом адаптації найкращих методів реалізації бізнес-процесів еталонних підприємств.

На основі наведених теоретичних положень бенчмаркінгу автором сформовано власний підхід моделі конщептуальних засад бенчмаркінгу аграрних підприємств (рис. 2).

\begin{tabular}{|c|c|c|}
\hline 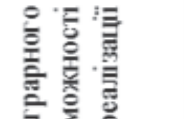 & & $\begin{array}{l}\text { Функціональне призначення }- \text { розробка доцільного } \\
\text { комплексу-маркетингу та напрямів конкурентного позиціонування, які } \\
\text { дозволяють реалізувати «парадигму відносин» }\end{array}$ \\
\hline 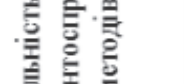 & $y$ & $\begin{array}{c}\text { Мета }- \text { підвишення конкурентоспроможності } \text { аграрних } \\
\text { підприемств шляхом аналізу конкурентів та еталонних підприємств }\end{array}$ \\
\hline 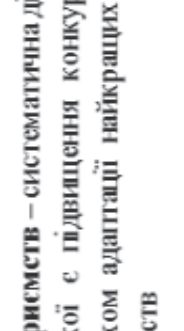 & & $\begin{array}{l}\text { Завдання: сприяння вивченню та встановлення мінімально } \\
\text { допустимих рівнів ефективності наявних на підприємстві процесів } \\
\text { видів діяльності; виявлення нагальних проблем і сфер діяльності, які } \\
\text { потребують удосконалення без залучення стороннього досвіду; аналіз } \\
\text { конкурентів та еталонних підприемств; розроблення пропозицій із } \\
\text { упровадження передового досвіду в рамках програми безперервного } \\
\text { удосконалення; посилення впливу факторів, що визначають } \\
\text { ефективність роботи; формування спільних поглядів і переваг у } \\
\text { співробітників }\end{array}$ \\
\hline 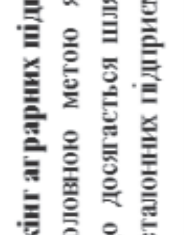 & & $\begin{array}{l}\text { Предмет дослідження - методи ведення бізнесу, шо } \\
\text { задовольняють потреби споживачів та зумовлюють іхню бажану } \\
\text { поведінку з врахуванням: } \\
\text { - факторів макросередовиша; } \\
\text { - факторів мікросередовиша; } \\
\text { - маркетинг-міксу }\end{array}$ \\
\hline 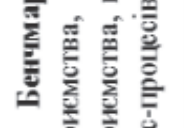 & & $\begin{array}{l}\text { Об'єкт дослідження - фактори конкурентних переваг, напрями } \\
\text { конкурентного позиціонування товарів, методи функціонування на } \\
\text { ринку та способи створення конкурентних переваг }\end{array}$ \\
\hline 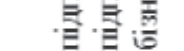 & & Джерела інформації: еталонні підприємства \\
\hline
\end{tabular}

Рис. 2. Модель концептуальних засад бенчмаркінгу аграрних підприємств Джерело: сорормовано та доповнено автором на основі [8].

Організаційно-економічний механізм використання бенчмаркінгу у підвищенні конкурентоспроможності аграрних підприємств є відкритою, динамічною системою організаційних, економічних, регулятивних, інституційних, управлінських методів, інструментів та рівнів, використання яких дає можливість перейняти кращий досвід суб'єктів господарювання та використовувати його в роботі інших підприємств, установ та організацій [11]. Формування та використання такого організаційно-економічного механізму має грунтуватися на принципах науковості, послідовності, доцільності, цілеспрямованості (табл. 2). 
Принципи організаційно-економічного механізму бенчмаркінгу аграрних підприємств

\begin{tabular}{|c|c|c|}
\hline $\begin{array}{c}\text { № } \\
3 / \Pi\end{array}$ & Принцип & Характеристика \\
\hline 1 & Науковості & $\begin{array}{l}\text { використання наукових знань у галузі } \\
\text { бенчмаркінгу аграрними підприємствами, аналіз } \\
\text { зарубіжного досвіду впровадження результатів } \\
\text { відповідних досліджень. Дотримання цього } \\
\text { принципу дозволяє також більш детально } \\
\text { розглянути всі аспекти цього методу, проаналізувати } \\
\text { його основні компоненти, типи, передумови } \\
\text { використання, що дає змогу визначити доцільність } \\
\text { його впровадження в в системі управління } \\
\text { підприємством }\end{array}$ \\
\hline 2 & Послідовності & $\begin{array}{l}\text { цей принцип полягає у розгляді організаційно- } \\
\text { економічного механізму бенчмаркінгу як цілісної } \\
\text { системи, в рамках якої взаємодіють його основні } \\
\text { зв'язки для забезпечення досягнення спільної мети. } \\
\text { Дотримання цього принципу сприяє формуванню } \\
\text { чіткого алгоритму застосування цього методу, } \\
\text { складових його реалізації, аналізу результатів. } \\
\text { Використання бенчмаркінгу дозволяє, застосовуючи } \\
\text { методологію системного підходу, чітко побудувати } \\
\text { графік відповідних досліджень, виявити осіб, } \\
\text { відповідальних за окремі етапи його впровадження. } \\
\text { Це, у свою чергу, спрощує весь процес використання } \\
\text { бенчмаркінгу в роботі сільськогосподарських } \\
\text { підприємств, дозволяє систематизувати отриману } \\
\text { інформацію, розподілити ії в окремі блоки та } \\
\text { поступово, всебічно описувати результати з чіткими } \\
\text { рекомендаціями щодо подальшого розвитку } \\
\text { аграрного підприємства }\end{array}$ \\
\hline 3 & Доцільності & 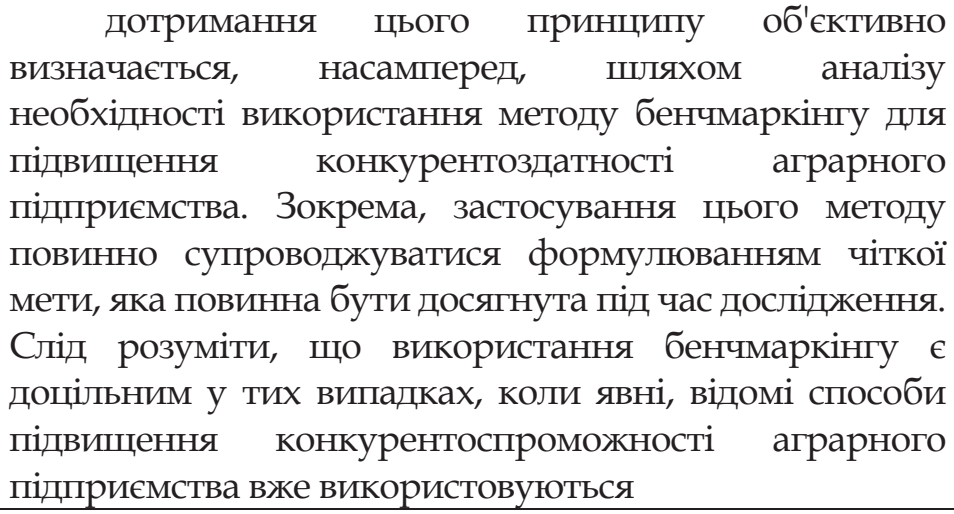 \\
\hline 4 & Цілеспрямованості & 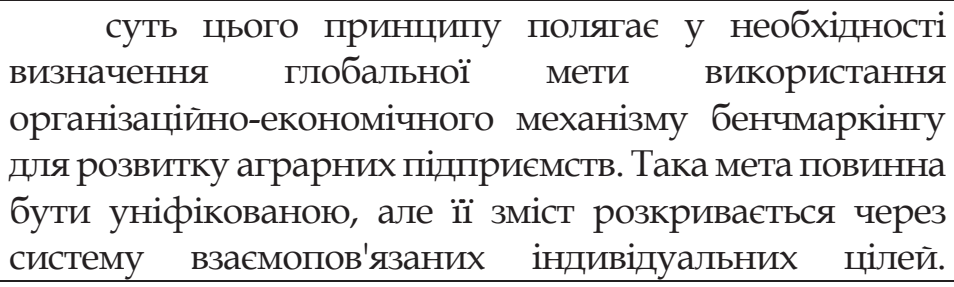 \\
\hline
\end{tabular}




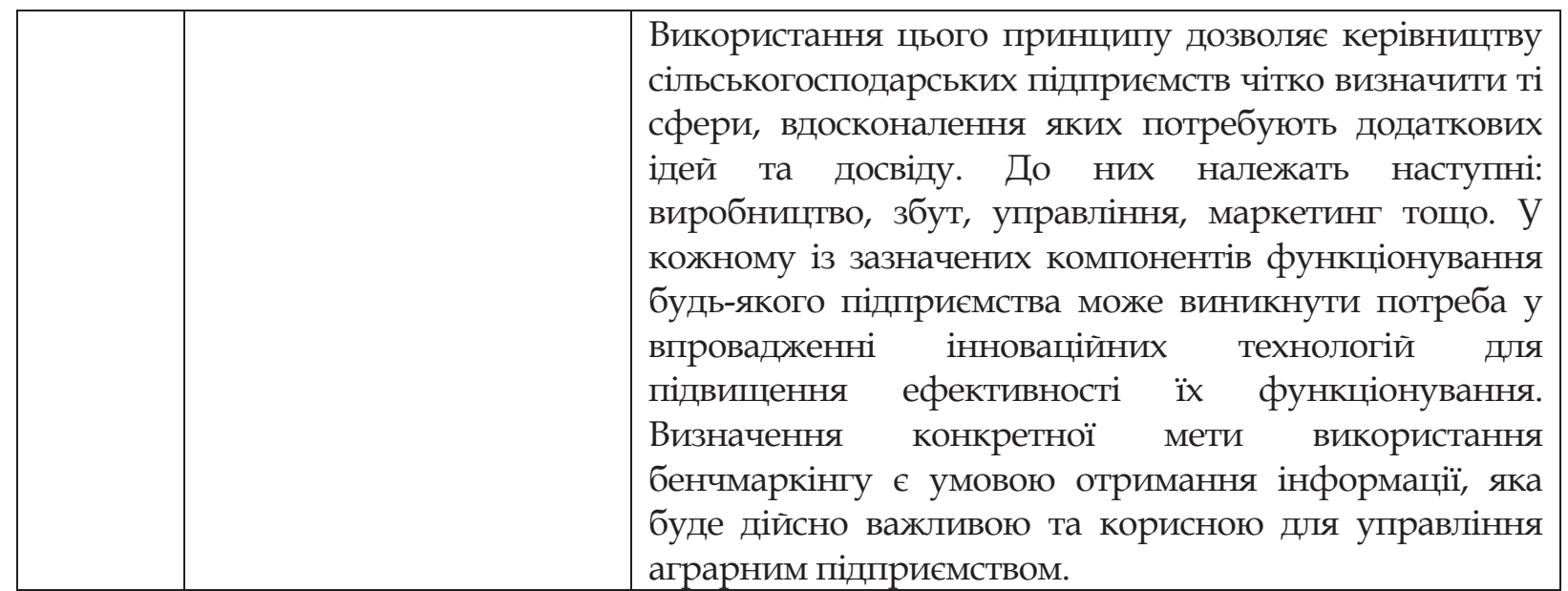

Джерело: сорормовано та доповнено автором на основі [8].

3 метою просування та полегшення використання бенчмаркінгу та обміну найкращими практиками, допомагаючи один одному та працюючи разом, створено Американський центр продуктивності та якості (найвищий авторитет у світі в галузі бенчмаркінгу, кращих практик, вдосконалення процесів і результатів, а також управління знаннями [4]) та Глобальну мережу бенчмаркінгу (альянс провідних організацій бенчмаркінгу у всьому світі, які поділяють спільне бачення, місію та цінності [5]). Зазначені організації дотримуються підходу щодо визначення бенчмаркінгу, за якого розуміють процес виявлення, вивчення та адаптації видатних практик та процесів будь-якої організації в будь-якій точці світу, щоб допомогти організації підвищити ії ефективність. Бенчмаркінг збирає мовчазні знання - ноухау, судження та сприяння.

В аграрній сфері у світі функціонує Agri Benchmarking, заснована Інститутом економіки сільського господарства Тюнена та Німецьким сільськогосподарським товариством, яка є глобальною неприбутковою мережею економістів, радників, виробників та спеціалістів у ключових галузях сільського господарства та садівництва [3]. Основні завдання функціонування Agri Benchmarking наведено на рисунку 3.

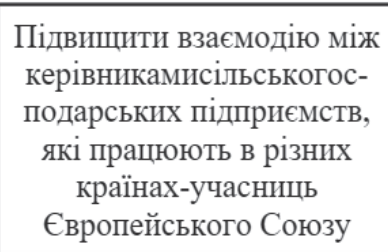

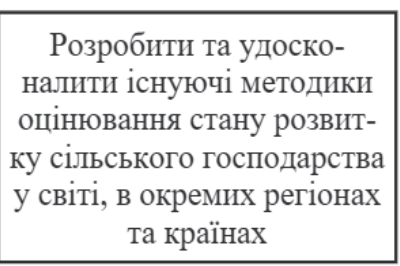

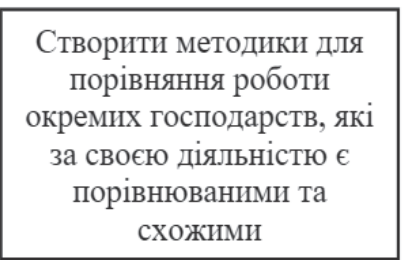

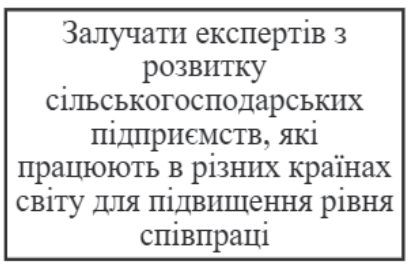
Сформувати платформу взаємодії між агровиробниками, урядовими та неурядовими інститутами, шукати спільні шляхи розвитку сільського господарства

Рис. 3. Основні завдання функціонування Agri Benchmarking

Джерело: сорормовано автором на основі [3]. 
В Україні на базі платформи Agrohub, яка займається поширенням знань про технології підвищення ефективності в агробізнесі, відкрито напрям бенчмаркінгу українських аграрних компаній, що здійснює аналіз конкурентів або різних підрозділів одного холдингу, який дозволяє спів ставляти їхні показники та визначати кращі галузеві практики [7].

Висновки. 3 метою уточнення сутності поняття «бенчмаркінг» для аграрних підприємств запропоновано використовувати динамічний підхід. Пропонується під бенчмаркінгом аграрних підприємств розуміти систематичну діяльність аграрного підприємства, головною метою якої $є$ підвищення конкурентоспроможності підприємства, що досягається шляхом адаптації найкращих методів реалізації бізнес-процесів еталонних підприємств.

Дослідження концептуальних засад бенчмаркінгу аграрних підприємств дозволило сформулювати власний підхід моделі концептуальних засад бенчмаркінгу аграрних підприємств, яка включає функціональне призначення, мету, завдання, предмет, об'єкт та інформаційне забезпечення бенчмаркінгу аграрних підприємств.

Розглянутий організаційно-економічний механізм бенчмаркінгу $\mathrm{y}$ підвищенні конкурентоспроможності аграрних підприємств дозволив встановити, що особливу роль у бенчмаркінгу відіграють профільні організації (наприклад, Американський центр продуктивності та якості, Agri Benchmarking) та платформи (в Україні такою платформою для аграрних підприємств є Agrohub), які здійснюють аналіз конкурентів, створюють методики порівняння роботи господарств, формують платформу для взаємодії між агровиробниками, урядовими та неурядовими інститутами, шукають спільні шляхи розвитку сільського господарства.

\section{Список використаних джерел:}

1. Морщенок Т. С. Бенчмаркінг як інструмент підвищення конкурентоспроможності підприємницьких структур. Економіка і суспільство. 2017. Вип. 9. С. 533-540.

2. Негоденко В., Щербата М. Теоретичні аспекти визначення сутності категорії "бенчмаркінг". Економічний аналіз. 2019. Т. 29(1). С. 208-214.

3. Офіційний сайт Agri Benchmarking. URL:

http://www.agribenchmark.org/home.html

4. Офіційний сайт Американського центру продуктивності та якості. URL: https:/ / www.apqc.org/

5. Офіційний сайт Глобальної мережі бенчмаркінгу. URL:

https:/ / www.globalbenchmarking.org

6. Офіційний сайт Державної служби статистики України. URL: http://www.ukrstat.gov.ua/

7. Офіційний сайт платформи Agrohub. URL: https://agrohub.ua.

8. Славіна Н. А., Лаврук О. С. Бенчмаркінг як інструмент маркетингової діяльності аграрного підприємства. Подільський вісник: сільське господарство, техніка, економіка. 2017. Вип. 26. С. 229-235.

9. Христенко О. В., Манжос С. А. Застосування бенчмаркінгу в системі управління підприємством. Фінансовий простір. 2018. № 1 (29). С. 153-158. 
10. Яців І., Бобровник Д. Імпелементація зарубіжного досвіду реалізації бенчмаркінгу в діяльності вітчизняних підприємств аграрної сфери.

Економічний аналіз. 2019. Вип. 29. № 2. С. 120-126.

11. Bobrovnyk D. O. Organizational-economic mechanism of the use of benchmarking in the activities of agricultural enterprises. Економіка АПК. 2020. № 3. C. 111-117. https:// doi.org/10.32317/2221-1055.202003111

12. Darrell K. Rigby Managment tools. Boston : Bain\&Company, Inc., 2013. P. 14-15.

\section{References:}

1. Morshchenok, T. S. (2017). Benchmarkinh yak instrument pidvyshchennia konkurentospromozhnosti pidpryiemnytskykh struktur [Benchmarking as a tool to increase the competitiveness of business structures]. Ekonomika i suspilstvo [Economy and society], iss. 9, 533-540. [in Ukrainian].

2. Nehodenko, V., Shcherbata, M. (2019). Teoretychni aspekty vyznachennia sutnosti katehorii "benchmarkinh" [Theoretical aspects of defining the essence of the category "benchmarking"]. Ekonomichnyi analiz [Economic analysis], vol. 29(1), 208214. [in Ukrainian].

3. Agri Benchmarking. URL: http://www.agribenchmark.org/home.html [in English].

4. American Productivity \& Quality Center. URL: https://www.apqc.org/ [in English].

5. Global benchmarking Network. URL: https://www.globalbenchmarking.org [in English].

6. Ofitsiinyi sait Derzhavnoi sluzhby statystyky Ukrainy [Official site of the State Statistics Service of Ukraine]. URL: http:/ / www.ukrstat.gov.ua/ [in Ukrainian].

7. Agrohub. URL: https://agrohub.ua. [in Ukrainian].

8. Slavina, N. A., Lavruk, O. S. (2017). Benchmarkinh yak instrument marketynhovoi diialnosti ahrarnoho pidpryiemstva [Benchmarking as a tool for marketing activities of an agricultural enterprise]. Podilskyi visnyk: silske hospodarstvo, tekhnika, ekonomika [Podolsky Journal: agriculture, engineering, economics], iss. 26, 229-235. [in Ukrainian].

9. Khrystenko, O. V., Manzhos, S. A. (2018). Zastosuvannia benchmarkinhu v systemi upravlinnia pidpryiemstvom [Application of benchmarking in the enterprise management system]. Finansovyi prostir [Financial space], no. 1 (29), 153-158. [in Ukrainian].

10. Yatsiv, I., Bobrovnyk, D. (2019). Implementatsiia zarubizhnoho dosvidu realizatsii benchmarkinhu $\mathrm{v}$ diialnosti vitchyznianykh pidpryiemstv ahrarnoi sfery [Implementation of foreign experience in the implementation of benchmarking in the activities of domestic agricultural enterprises]. Ekonomichnyi analiz [Economic analysis], iss. 29, no. 2, 120-126. [in Ukrainian].

11. Bobrovnyk, D. O. (2020). Organizational-economic mechanism of the use of benchmarking in the activities of agricultural enterprises. Ekonomika APK [Economics of agro-industrial complex], no. 3, 111-117. https://doi.org/10.32317/2221-1055.202003111 [in English].

12. Darrell, K. Rigby (2013). Managment tools. Boston : Bain\&Company, Inc. [in English]. 